\title{
MENINGKATKAN PRESTASI DAN MOTIVASI BELAJAR IPA DENGAN MENERAPKAN PENGAJARAN BERBASIS INKUIRI DI SD TELAGA ARUM
}

\author{
Mulyadi \\ Guru SDN 4 Telaga Arum \\ Email: mulyadisdn4seponti@gmail.com
}

\begin{abstract}
Abstrak
Untuk bisa mempelajari sesuatu dengan baik, kita perlu mendengar, melihat, mengajukan pertanyaan tentangnya, dan membahasnya dengan orang lain. Bukan Cuma itu, siswa perlu "mengerjakannya", yakni menggambarkan sesuatu dengan cara mereka sendiri, menunjukkan contohnya, mencoba mempraktekkan keterampilan dan mengerjakan tugas yang menuntut pengetahuan yang telah mereka dapatkan. Sedangkan tujuan dari penelitian ini adalah: (a) Ingin mengetahui seberapa jauh pemahaman dan penguasaan mata pelajaran IPA setelah diterapkannya pengajaran berbasis inkuiri. (b) Ingin mengetahui pengaruh motivasi belajar siswa setelah diterapkan pengajaran berbasis inkuiri. Penelitian ini menggunakan penelitian tindakan (action research) sebanyak tiga putaran. Setiap putaran terdiri dari empat tahap yaitu: rancangan, kegiatan dan pengamatan, refleksi, dan refisi. Sasaran penelitian ini adalah siswa kelas V SDN 4 Telaga Arum semester genap tahun pelajaran 2019/2020 Data yang diperoleh berupa hasil tes formatif, lembar observasi kegiatan belajar mengajar. Dari hasil analis didapatkan bahwa prestasi belajar siswa mengalami peningkatan dari siklus I sampai siklus III yaitu, siklus I $(62,50 \%)$, siklus II $(75,00 \%)$, siklus III $(87,50 \%)$. Simpulan dari penelitian ini adalah metode pengajaran berbasis inkuiri dapat berpengaruh positif terhadap motivasi belajar Siswa kelas V SDN 4 Telaga Arum semester genap tahun pelajaran 2019/2020, serta model pembelajaran ini dapat digunakan sebagai salah satu alternative pembelajaran IPA
\end{abstract}

Kata Kunci: Prestasi Belajar, Motivasi Belajar, Pengajaran Berbasis Inkuiri

\section{PENDAHULUAN}

Salah satu permasalahan yang dihadapi oleh bangsa Indonesia adalah rendahnya mutu pendidikan, khususnya pendidikan dasar dan menengah. Berbagai usaha telah dilakukan untuk menigkatkan mutu pendidikan nasional, antara lain melalui berbagai pelatihan dan peningkatan kualitas guru, penyempurnaan kurikulum, pengadaan buku dan alat pelajaran, perbaikan sarana dan prasarana pendidikanlain, dan peningkatan mutu manajemen sekolah, namun demikian, berbagai indikator mutu pendidikan belum menunjukkan peningkatan yang memadai.

Mengajar bukan semata persoalan menceritakan. Belajar bukanlah konsekuensi otomatis dari perenungan informasi ke dalam benak siswa. Belajar memerlukan keterlibatan mental dan kerja siswa sendiri. Penjelasan dan pemeragaan semata tidak akan membuahkan hasil belajar yang langgeng. Yang bisa membuahkan hasil belajar yang langgeng hanyalah kegiatan pengajaran berbasis inkuiri. Apa yang menjadikan pengajaran menjadi aktif? Agar belajar menjadi aktif siswa harus mengerjakan banyak sekali tugas. Mereka harus menggunakan otak, mengkaji gagasan, memecahkan masalah, dan menerapkan apa yang mereka pelajari. Pengajaran berbasis inkuiri harus gesit, menyenangkan, bersemangat dan penuh gairah. Siswa bahkan sering meninggalkan tempat duduk mereka, bergerak leluasa dan berfikir keras (moving about dan thinking aloud)

Untuk bisa mempelajari sesuatu dengan baik, kita perlu mendengar, melihat, mengajukan pertanyaan tentangnya, dan membahasnya dengan orang lain. Bukan Cuma itu, siswa perlu "mengerjakannya", yakni menggambarkan sesuatu dengan cara mereka sendiri, menunjukkan contohnya, mencoba mempraktekkan keterampilan, dan mengerjakan tugas yang menuntut pengetahuan yang telah atau harus mereka dapatkan. 
Berdasarkan uraian tersebut di atas penulis mencoba menerapkan salah satu metode pembelajaran, yaitu metode pembelajaran berbasis inkuiri untuk mengungkapkan apakah dengan model berbasis inkuiri dapat meningkatkan motivasi belajar dan prestasi sains. Dalam metode pembelajaran berbasis inkuiri siswa lebih aktif dalam memecahkan untuk menemukan sedang guru berperan sebagai pembimbing atau memberikan petunjuk cara memecahkan masalah itu.

Dengan menyadari gejala-gejala atau kenyataan tersebut diatas, maka dalam penelitian ini penulis penulis mengambil judul "Meningkatkan Prestasi dan Motivasi Belajar IPA Dengan Menerapkan Pengajaran Berbasis Inkuiri Pada Siswa Kelas V SDN 4 Telaga Arum Semester Genap Tahun Pelajaran 2019/2020"

Bertitik tolak dari latar belakang diatas maka penulis merumuskan permasalahnnya sebagi berikut: (1) Bagaimanakah peningkatan prestasi belajar siswa dengan diterapkannya pengajaran berbasis inkuiri pada siswa Kelas $\mathrm{V}$ tahun pelajaran 2019/2020? (2) Bagaimanakah pengaruh model pengajaran berbasis inkuiri terhadap motivasi belajar siswa

Sesuai dengan permasalahan di atas, penelitian ini bertujuan untuk: (1) Ingin mengetahui seberapa jauh pemahaman dan penguasaan mata pelajaran IPA setelah diterapkannya pengajaran berbasis inkuiri pada siswa Kelas V tahun Pelajaran 2019/2020. (2) Mengetahui pengaruh motivasi belajar siswa setelah diterapkan pengajaran berbasis inkuiri dalam membangunkan ingatan siswa terhadap materi pelajaran IPA setelah diterapkan pengajaran berbasis inkuiri pada siswa Kelas V tahun Pelajaran 2019/2020

Adapun maksud penulis mengadakan penelitian ini diharapkan dapat berguna sebagai: (1) Menambah pengetahuan dan wawasan penulis tentang peranan guru dalam meningkatkan pemahaman siswa belajar IPA. (1) Sumbangan pemikiran bagi guru dalam mengajar dan meningkatkan pemahaman siswa belajar IPA di Kelas V SDN 4 Telaga Arum semester genap tahun Pelajaran 2019/2020. (2) Meningkatkan motivasi belajar IPA. (3) Mengembangkan metode pembelajaran yang sesuai dengan bidang studi IPA.
Karena keterbatasan waktu, maka diperlukan pembatasan masalah yang meliputi: (1) Penelitian ini hanya dikenakan pada siswa kelas V SDN 4 Telaga Arum semester genap Tahun Pelajaran 2019/2020. (1) Penelitian ini dilaksanakan pada bulan September tahun Pelajaran 2019/2020. (2) Materi yang disampaikan adalah pokok bahasan Daur Air.

Pengertian belajar sudah banyak dikemukakan dalam kepustakaan. Yang dimaksud belajar yaitu perbuatan murid dalam bidang material, formal serta fungsional pada umumnya dan bidang intelektual pada khususnya. Jadi belajar merupakan hal yang pokok. Belajar merupakan suatu perubahan pada sikap dan tingkah laku yang lebih baik, tetapi kemungkinan mengarah pada tingkah laku yang lebih buruk.

Untuk dapat disebut belajar, maka perubahan harus merupakan akhir dari pada periode yang cukup panjang. Berapa lama waktu itu berlangsung sulit ditentukan dengan pasti, tetapi perubahan itu hendaklah merupakan akhir dari suatu periode yang mungkin berlangsung berharihari, berminggu-minggu, berbulan-bulan atau bertahun-tahun. Belajar merupakan suatu proses yang tideak dapat dilihat dengan nyata proses itu terjadi dalam diri seserorang yang sedang mengalami belajar. Jadi yang dimaksud dengan belajar bukan tingkah laku yang nampak, tetapi prosesnya terjadi secara internal di dalam diri individu dalam mengusahakan memperoleh hubungan-hubungan baru.

Sebelum dijelaskan pengertian mengenai prestasi belajar, terlebih dahulu akan dikemukakan tentang pengertian prestasi. Prestasi adalah hasil yang telah dicapai. Dengan demikian bahwa prestasi merupakan hasil yang telah dicapai oleh seseorang setelah melakukan sesuatu pekerjaan/aktivitas tertentu.

Jadi prestasi adalah hasil yang telah dicapai oleh karena itu semua individu dengan adanya belajar hasilnya dapat dicapai. Setiap individu belajar menginginkan hasil yang yang sebaik mungkin. Oleh karena itu setiap individu harus belajar dengan sebaik-baiknya supaya prestasinya berhasil dengan baik. Sedang pengertian prestasi juga ada yang mengatakan prestasi adalah kemampuan. Kemampuan di sini berarti yan dimampui individu dalam mengerjakan sesuatu.

Untuk memperoleh prestasi/hasil belajar yang baik harus dilakukan dengan baik dan pedoman 
cara yang tapat. Setiap orang mempunyai cara atau pedoman sendiri-sendiri dalam belajar. Pedoman/cara yang satu cocok digunakan oleh seorang siswa, tetapi mungkin kurang sesuai untuk anak/siswa yang lain. Hal ini disebabkan karena mempunyai perbedaan individu dalam hal kemampuan, kecepatan dan kepekaan dalam menerima materi pelajaran.

Oleh karena itu tidaklah ada suatu petunjuk yang pasti yang harus dikerjakan oleh seorang siswa dalam melakukan kegiatan belajar. Tetapi faktor yang paling menentukan keberhasilan belajar adalah para siswa itu sendiri. Untuk dapat mencapai hasil belajar yang sebaik-baiknya harus mempunyai kebiasaan belajar yang baik.

Adapun faktor-faktor itu, dapat dibedakan menjadi dua golongan yaitu: (1) Faktor yang ada pada diri siswa itu sendiri yang kita sebut faktor individu. Yang termasuk ke dalam faktor individu antara lain faktor kematangan atau pertumbuhan, kecerdasan, latihan, motivasi, dan faktor pribadi. (2) Faktor yang ada pada luar individu yang kita sebut dengan faktor social. Sedangkan yang faktor sosial antara lain faktor keluarga, keadaan rumah tangga, guru, dan cara dalam mengajarnya, lingkungan dan kesempatan yang ada atau tersedia dan motivasi sosial.

Berdasarkan faktor yang mempengaruhi kegiatan belajar di atas menunjukkan bahwa belajar itu merupaka proses yang cukup kompleks. Artinya pelaksanaan dan hasilnya sangat ditentukan oleh faktor-faktor di atas. Bagi siswa yang berada dalam faktor yang mendukung kegiatan belajar akan dapat dilalui dengan lancar dn pada gilirannya akan memperoleh prestasi atau hasil belajar yang baik.

Sebaliknya bagi siswa yang berada dalam kondisi belajar yang tidak menguntungkan, dalam arti tidak ditunjang atau didukung oleh faktorfaktor diatas, maka kegiatan atau proses belajarnya akan terhambat atau menemui kesulitan.

IPA didefiniksan sebagai suatu kumpulan pengetahuan yang tersusun secara alam. Perkembangan IPA tidak hanya ditandai dengan adanya fakta, tetapi juga oleh adanya metode ilmiah dan sikap ilmiah. Metode ilmiah dan pengamatan ilmiah menekankan pada hakikat IPA.

Secara rinci hakikat IPA menurut Bridgman (dalam Lestari, 2002: 7) adalah sebagai berikut: (1) Kualitas; pada dasarnya konsep-konsep IPA selalu dapat dinyatakan dalam bentuk angka- angka. (2) Observasi dan Eksperimen; merupakan salah satu cara untuk dapat memahami konsepkonsep IPA secara tepat dan dapat diuji kebenarannya. (3) Ramalan (prediksi); merupakan salah satu asumsi penting dalam IPA bahwa misteri alam raya ini dapat dipahami dan memiliki keteraturan. Dengan asumsi tersebut lewat pengukuran yang teliti maka berbagai peristiwa alam yang akan terjadi dapat diprediksikan secara tepat. (4) Progresif dan komunikatif; artinya IPA itu selalu berkembang ke arah yang lebih sempurna dan penemuan-penemuan yang ada merupakan kelanjutan dari penemuan sebelumnya. Proses; tahapan-tahapan yang dilalui dan itu dilakukan dengan menggunakan metode ilmiah dalam rangkan menemukan suatu kebernaran. (5) Universalitas; kebenaran yang ditemukan senantiasa berlaku secara umum.

Dari penjelasan di atas, dapat disimpulkan bahwa hakikat IPA merupakan bagian dari IPA, dimana konsep-konsepnya diperoleh melalui suatu proses dengan menggunakan metode ilmiah dan diawali dengan sikap ilmiah kemudian diperoleh hasil (produk). Pembelajaran dengan penemuan (inquiry) merupakan satu komponen penting dalam pendekatan konstruktivistik yang telah memiliki sejarah panjang dalam inovasi atu pembaharuan pendidikan. Dalam pembelajaran dengan penemuan/inkuiri, siswa didorong untuk memiliki pengalaman dan melakukan percobaan yang memungkinkan mereka menemukan prinsipprinsip untuk diri mereka sendiri, Bruner (1966), penganjur pembelajaran dengan basis inkuiri, menyatakan sebagai berikut: "Kita mengajarkan suatu bahan kajian tidak untuk menghasilkan perpustakaan hidup tentang bahan kajian itu, tetapi lebih ditujukan untuk membuat siswa berpikir .... Untuk diri mereka sendiri, meneladani seperti apa yang dilakukan oleh seorang sejarawan, mereka turut mengambil bagian dalam proses, bukan suatu produk (Nur \& Wikandari, 2000:10). Belajar dengan penemuan dapat diterapkan dalam banyak mata pelajaran. Sebagai contoh, siswa diberi sederet silinder dengn ukuran dan berat yang berbeda-beda. Siswa diminta untuk menggelindingkan silinder tersebut pada suatu bidang miring. Bila percobaan itu dilakukan dengan benar, siswa akan dapat menemukan prinsip-prinsip utama yagn menentuan kecepatan silinder tersebut. 
Belajar dengan penemuan mempunyai berbagai keuntungan. Pembelajaran dengan inkuiri memacu keinginan siswa untuk mengetahui, memotivasi mereka untuk melanjutan pekerjaannya hingga mereka menemukan prinsipprinsip utama yang menentukan kecepatan silinder tersebut. Belajar dengan penemuan mempunyai beberapa keuntungan. Pembelajaran dengan inkuiri memacu keinginan siswa untuk mengetahui, memotivasi mereka untuk melanjutkan pekerjaannya hingga mereka menemukan jawabannya. Siswa juga belajar memecahkan masalah secara mandiri dan memiliki keterampilan berpikir kritis karena mereka harus selalu menganalisa dan menangani informasi.

Pengajaran berbasis inkuiri membutuhkan strategi pengajar yang mengikuti metodologi IPA dan menyediakan kesempatan untuk pembelajaran bermakna. Inkuiri adalah seni dan ilmu bertanya dan menjawab. Inkuiri melibatkan observasi dan pengukuran, pembutan hipotesis dan interpretasi, pembentukan model dan pengujian model. Inkuiri menuntut adanya eksperimentasi, refleksi, dan pengenalan akan keunggulan dan kelamahan metode-metodenya sendiri.

Selama proses inkuiri berlangsung, seorang guru dapat menajukan suatu pertanyaan atau mendorong siswa untuk mengajukan pertanyaanpertanyaan mereka sendiri. Pertanyaannya bersifat open-ended, memberi kesempatan kepada siswa untuk menyelidiki sendiri dan mereka mencari jawaban sendiri (tetapi tidak hanya satu jawaban yang benar).

Inkuiri adalah apa yang dibuat oleh para ilmuwan. Para ilmuwan melakukan ikuiri dengan suatu cara formal dan sitematis, dan dalam proses melakukan inkuiri para ilmuwan memberikan kontribusi pada tubuh informasi yang bersifat kolektif yang kita sebut pengetahuan. Dalam proses mengalami ilmu melalui inkuiri, siswa belajar bagaiman menjadi ilmuwan. Mereka belajar lebih banyak lagi ketimbang hanya konsep dan fakta, mereka mempelajari berbagi proses yang terlibah dalam pemantapan konsep dan fakta.

Inkuiri memberikan kepada siswa pengalaman-pengalaman belajar yang nyata dan aktif. Siswa diharapkan mengambil inisiatif. Mereka dilatih bagaimana memecahkan maslah, membuat keputusan, dan memperoleh ketarampilan. Inkuiri memeungkinkan siswa dalam berbgai tahap perkembangannya bekerja dengan masalah-masalah yang sama dan bahkan mereka bekerja sama mencari solusi terhadap masalah-masalah. Setiap siswa harus memainkan dan memfungsikan talentanya masing-masing.

Inkuiri memungkinkan terjadinya integrasi berbagai disiplin ilmu. Ketika siswa melakukan eksplorasi mereka cenderung mengajukan pertanyaan-pertanyaan yang akan melibatkan IPA dan matematika, ilmu sosial, bahasa, seni, dan teknik. Inkuiri melibatkan pula komunikasi. Siswa harus mengajukan pertanyaan-pertanyaan yang berarti dan berhubungan. Mereka harus melapoirkan hasil-hasil temuannya, lisan atau tertulis. Dengan begitu, mereka bekerja dan mengajar satu sama lain. Inkuiri memungkinkan guru mempelajari siswa-siswanya - siapa mereka, apa yang mereka ketahui, dan bagaimana mereka bekerja. Pemahaman guru tentang siswa akan memungkinkan guru untuk menjadi fasilitator yang lebih efektif dalam proses pencarian ilmu oleh siswa.

Ketika guru menggunakan teknik inkuiri, guru tidak boleh banyak bertanya atau berbicara. Terlalu banyak intervensi, terlalu banyak bertanya, dan terlalu banyak menjawab akan mengurangi proses belajar siswa melalui inkuiri. Dengan demikian, proses belajar tidak akan lagi menyenangkan. Dalam proses inkuiri, siswa dituntut untuk bertanggung jawab bagi pendidikan mereka sendiri. Guru yang menaruh perhatian pada pribadi siswa, akan menemukan kegiatankegiatan yang disukai siswa, juga hal-hal yng baik yag ada dalam diri siswa-siswanya, dan kesulitiankesulitan yang mengganggu siswa dalam proses belajar. Guru dituntut menyesuaikan diri terhadap gaya belajara siswa-siswanya.

Siklus inkuiri adalah: (1) Observasi (Observation); (2) Bertanya (Questioning); (3) Mengajukan dugaan (Hipothesis); (4) Pengumpulan data (Data Gathering); dan Penyimpulan (Conclusion).

Inkuiri adalah satu proses yang bergerak dari langkah observasi sampai langkah pemahaman. Inkuiri dimulai dengan observasi yang menjadi dasar pemunculan berbagai pertanyaan yang diajukan siswa. Jawaban terhadap pertanyaanpertanyaan tersebut dikejar dan diperoleh melalui suatu siklus pembuatan prediksi, perumusan hipotesis, pengembangan cara-cara pengujian hipotesis, pembuatan observasi lanjutan, 
penciptaan teori dan model-model konsep yang didasarkan pada data dan pengetahuan. Inkuiri menciptakan berbagai kesempatan bagi guru untuk mempelajari bagaimana otak siswa bekerja. Guru dapat memanfaatkannya untuk menentukan situasi-situasi belajar yang tepat dan memfasilitasi siswa dalam proses pencarian ilmu.

Dalam proses inkuiri, siswa belajar dan dilatih bagaimana mereka harus berpikir kritis. Berpikir kritis merupakan slah satu tujuan pendidikan. Ketika siswa belajar berpikir kritis, merka kan memperlihatkan pikiran-pikiran dan proses-proses sebagai berikut: (1) Mengajukan pertanya seperti "Bagaimana itu kita tahu?" atau "Apa buktinya?" (2) Mengetahui perbedaan antara observasi dan kesimpulan. (3) Mengetahui bahwa semua gagasan ilmiah itu dapat berubah dan bahwa teori yang ada adalah teori-teori yang terbaik berdasarkan bukti yang kita miliki sejuh nini. (4) Mengetahui bahwa diperlukan bukti yang cukup untuk menarik suatu kesimpulan yang kuat. (5) Memberi penjelasan atau interpretasi, memalkukan observasi dan/atau prediksi. (6) Selalu mencari konsistensi terhadap kesimpulankesimpulan yang diambil dan memgerikan penjelasan dengan rasa percaya diri.

Salah satu tujuan utama pendidikan adalah meningkatkan kemampuan siswa untuk berpikir kritis, membuat keputusan rasional tentang apa yang diperbuat atau apa yang diyakini.seperti halnya setiap tujuan yang lain, belajar berpikir kritis bergantung pada penataan suasana kelas yang mendorong penerimaan pandangan divergen (berbeda) dan diskusi bebas. Tatanan itu seharusnya juga lebih menekankan pada pemberian alasan atau pandangan daripada hanya memberikan jawaban benar. Keterampilan dalam berpikir kritis paling baik dicapai bila dihibungkan dengan topik-topik yang dikenal siswa. Tujuan pengajaran berpikir kritis adalah menciptakan suatu semangat berpikir kritis yang mendorong siswa mempertanyakan apa yang mereka dengar dan mengkaji pikiran mereka sendiri untuk memastikan tidak terjadi logika yang tidak konsisten atau keliru.

Beyer (1988:57) mengidentifiksi 10 keterampilan berpikir kritis yang dpat digunakan siswa untuk mempertimbangkan validitas (keabsahan) tuntutan atau argument, memahami periklanan, dan sebagainya. (1) Membedakan fakta-fakta yang dapat diverifikasi dan tuntutan nilai-nilai yang sulit diverifikasi (diuji kebenarannya). (2) Membedakan antara informasi, tuntutan, atau alasan yang relevan dengan yang tidak relevan. (3) Menentukan kecermatan factual (kebenaran) dari suatu penyataan. (4) Menentukan kredibilitas (dapat dipercaya) dari suaut sumber. (5) Mengidentifikasi tuntutan atau argument yang mendua. (6) Mengidentifikasi asumsi yang tidak dinyatakn. (7) Mendeteksi bias (menemukan penyimpangan). (8) Mengidentifikasi kekeliruankekeliruan logika. (9) Mengenali ketidakkonsistenan logika dalam suatu alur penalaran. (10) Menentukan kekuatan suatu argument atau tuntutan.

Beyer mengingatkan bahwa 10 keterampilan berpikir kritis di atas bukan merupakan suatu urutan langkah-langkah tetapi lebih merupakan daftar cra yang dapat dilakukan. Dengan cara-cara itu, siswa dapat menangani informasi untuk mengevaluasi apakah informasi itu benar atau masuk akal. Tugas utama dalam mengajarkan berpikir kritis kepada siswa adalah membantu mereka belajar tidak hanya bagaimana menggunakan tiap-tiap strategi berpikir kritis itu, tetapi juga menyampaikan kapan tiap-tiap strategi berpikir kritis itu cocok untuk dipakai.

Proses inkuiri tidak dpat dipisahkan dari konsep berpikir kritis. Konsep berpikir kritis tidak dapat pula dipisahkan dari konsep inteligensi. Inteligensi bukan sesuatu yang hanya dpat diukur dengan tes, buan pula sesuatu yang semata-mata pembawaan genetis secara lahiriah. Howard Gardaner (1983) menunjukan bahwa intelgensi dapat diubah. "Intelligence is the ability to solve problems or to create products that are valued between one or more cultural settings" (Johnson, 2002:141). Intelligensi tidak dapat dipisahkan dari konteks di mana manusia itu hidup dan berkembang.

Menurut Gardaner, inteligensi tidak dilahirkan, tapi dapat berkembang atau berkurang, bergantung pada lingkungan atau konteks seseorang. Lingkungan yang dimaksud adalah teman, guru, orang tua, buku, alat-alat belajar (pena, computer, kegiatan-kegiatan fisik, musik), dan hal-hal lain yang mencapai otak melalui panca indera. Dengan menggunakan kriteria khusus untuk mengidentifikasi konsep inteleigenais, Gardaner mengusulkan delapan jenis inteligenwsi, yakni: linguistic, logical-mathematic, musical, spatial, bodily-kinesthetic, interpersonal, intra- 
personal, dan naturalist. Jenis pekerjan dan aktivitas yang dapat dikembangkan untuk kedelapan jenis inteligensi ini dpat dicontohkan sebagai beikut: (1) linguistic: wartawan, reporter, politikus, atau penulis; (2) logis-mathematis; ahli fisika, neurology, atau insinyur; (3) spasial: pelukis, interior decorator, atau pemain tennis; (4) bodily-kinesthic: penari balet, pemain golf, pembalap, atau petinju; (5) musik: pengarang lagu, penyanyi, atau organis/pianis; (6) interpersonal: hakim, saleperson, atau guru; (7) intrapersonal: biarawan/rohaniawan, pujangga, atau ahli ilmu jiwa/psikolog; dan (8) naturalist: ahli botani, ahli kebun binatang, atau ahli pertamanan.

Kedelapan jenis inteligensi ini telah mengilhami para pendidik untuk mengajar dengan dengan mengac pada salah satu dari delapan jenis inteligensi tersebut. "Hundred, perhaps thousands, of classrooms around the world rely today on Gardaner's theory of multiple intelligences to help students realize their latent potential" (Johnson,
2002:141). Apakah kelas berfokus pada siswa yang kurang mampu atau kelas yang siswasiswanya berbakat, para pendidik melihat manfaat mengajar yang sesuai dengan cara-cara untuk mencapai berbagai jenis inteligensi yang dikemukakan Gardaner.

Setiap siswa mampu mengembangkan setiap jenis inteligensidi atas dengan asumsi bahwa siswa belajar dalam suatu lingkungan belajar yang kaya yang memungkikan mereka menghubungkan makna dengan konteks. "CTL's component work together to provide this rich environment, offering students many opportunities to ignite the eight multiple intelligences" (Amstrong, 1994:35). Guru CTL menyadari dan menghargai bahwa setiap anak memiliki derajat yang berbeda dalam hal inteligensinya dan bahwa CTL sebagai suatu system holistic berhubungan dengan delapan inteligensi yang dibawa setiap anak pada lingkungan belajar.

Tabel 1. Delapan Inteligensi (Howard Gardaner, 1983)

\begin{tabular}{ll}
\hline & Multiple Intelligences \\
\hline Logika-matematika & Peka terhadap pola, keterampilan dan sistematika. \\
\hline Linguistic/ilmu bahasa & Peka terhadap bunyi, ritme, dan makna kata \\
\hline Musik & $\begin{array}{l}\text { Kemapuan menghasilkan dan menghargai ritme, tinggi rendah } \\
\text { suara, dan warna suara }\end{array}$ \\
\hline Spatial/jarak & $\begin{array}{l}\text { Kemampuan untuk melakukan transformasi mengenai } \\
\text { persepsi awal seseorang dan kemampuan mengkreasi kembali } \\
\text { aspek-aspek pengalaman visual seseorang. }\end{array}$ \\
\hline Bodily-kinesthetic/fisik-kinestetik & $\begin{array}{l}\text { Kemampuan mengontrol gerak tubuh seseorangdan } \\
\text { kemampuan menangani objek secara terampil. }\end{array}$ \\
\hline \multirow{2}{*}{ Inter personal/antar-pribadi } & $\begin{array}{l}\text { Kemampuan untuk menjawab atu memberikan reaksi secara } \\
\text { tepat berbagai suasana batin, temperamen, motivasi dan } \\
\text { keinginanorang lain. }\end{array}$ \\
\hline Intapersonal/antar-pribadi & $\begin{array}{l}\text { Bagaimana menjiwai perasaan sendiri, kemampuan } \\
\text { mendiskriminasikan berbagi perasaan seseorang, dan } \\
\text { kemampuan menarik kesimpulan untuk menuntun tingkah } \\
\text { laku seseorang }\end{array}$ \\
\hline Naturalist/alamiah & $\begin{array}{l}\text { Mengamati, mengalami dan mengorganisasikan berbagai pola } \\
\text { dalam lingkungan alamiah }\end{array}$ \\
\hline
\end{tabular}

Guru yang menggunakan pembelajaran berbasis inkuiri haru menjadikan siswa mampu berdiri sendiri, harus mendorong siswa untuk mandiri sedini mungkin sejak dari awal masuk sekolah. Timbul pertanyaan, bagaimana caranya guru membantu siswa agar mereka tumbuh mandiri? Jawabannya adalah memberi kebebasan kepada siswa untuk mengikuti minat alamiah mereka. Guru harus mendorong siswa untuk memecahkan sendiri msalah yang dihadapinnya atau memecahkan sendiri di dalam kelompoknya, bukan mengajarkan mereka jawaban dari masalah yang mereka hadapi. Siswa akan mendapat keuntungan jika mereka dapat "melihat" dan 
"melakukan" sesuatu daripada hanya sekedar mendengarkan ceramah atau penjelasan guru. Guru dapat membantu siswa memahami konsepkonsep yang sulit dengan bantuan gambar dan demontrasi.

Belajar harus luwes dan bersifat menyelidiki atau melalui penemuan. Jika siswa tampak berusaha dengan menghadapi suatu, berikan mereka waktu untuk mencoba sendiri memecahkan masalah tersebut sebelum memberikan pemecahannya. Guru juga harus memperhatikan sikap siswa terhadap belajar. Menurut Jerome, S. Burner, sekolah harus merangsang keingintahuan siswa, meminimalkan risiko kegagalan, dan bertindak serelevan mungkin bagi siswa. Sebagai saran tamhahan bagi guru yangmengajar dengan pendekatan inkuiri: (1) doronglah siswa agar mereka mengajukan dugan awal dengan cara guru mengajukan pertanyaanpertanyaan membimbing; (2) gunakan bahan dan permainan yang bervariasi; (3) berikan kesempatan kepada siswa untuk memuaskan keingintahuan mereka, meskipun mereka mengajukan gagasan-gagasan yang tidak berhubungan langsung dengan pelajaran yang diberikan; dan (4) gunakan sejumlah contoh yang kontras atau perlihatkan perbedaan yang nyata dengan materi ajar mengenai topik-topik yang terkait.

\section{METODE PENELITIAN}

Penelitian ini merupakan penelitian tindakan (action research), karena penelitian dilakukan untuk memecahkan masalah pembelajaran di kelas. Penelitian ini juga termasuk penelitian deskriptif, sebab menggambarkan bagaimana suatu teknik pembelajaran diterapkan dan bagaimana hasil yang diinginkan dapat dicapai. Menurut Oja dan Sumarjan (dalam Titik Sugiarti, 1997: 8) mengelompokkan penelitian tindakan menjadi empat macam yaitu, (a) guru sebagai penelitia; (b) penelitian tindakan kolaboratif; (c) simultan terintegratif; (d) administrasi social eksperimental.

Dalam penelitian tindakan ini menggunakan bentuk guru sebagai peneliti, penanggung jawab penuh penelitian ini adalah guru. Tujuan utama dari penelitian tindakan ini adalah untuk meningkatkan hasil pembelajaran di kelas dimana guru secara penuh terlibat dalam penelitian mulai dari perencanaan, tindakan, pengamatan, dan refleksi.

Dalam penelitian ini peneliti tidak bekerjasama dengan siapapun, kehadiran peneliti sebagai guru di kelas sebagai pengajar tetap dan dilakukan seperti biasa, sehingga siswa tidak tahu kalau diteliti. Dengan cara ini diharapkan didapatkan data yang seobjektif mungkin demi kevalidan data yang diperlukan.

Tempat penelitian adalah tempat yang digunakan dalam melakukan penelitian untuk memperoleh data yang diinginkan. Penelitian ini bertempat di SDN 4 Telaga Arum semester genap tahun Pelajaran 2019/2020. Waktu penelitian adalah waktu berlangsungnya penelitian atau saat penelitian ini dilangsungkan. Penelitian ini dilaksanakan pada bulan Februari sampai dengan Mei tahun Pelajaran 2019/2020

Subyek penelitian adalah siswa-siswi Kelas V semester genap tahun pelajaran 2019/2020 pada pokok bahasan Daur Air. Penelitian ini menggunakan Penelitian Tindakan Kelas (PTK). Menurut Tim Pelatih Proyek PGSM, PTK adalah suatu bentuk kajian yang bersifat reflektif oleh pelaku tindakan yang dilakukan untuk meningkatkan kemantapan rasional dari tindakan mereka dalam melaksanakan tugas, memperdalam pemahaman terhadap tindakan-tindakan yang dilakukan itu, serta memperbaiki kondisi dimana praktek pembelajaran tersebut dilakukan (dalam Mukhlis, 2000: 3).

Sedangkah menurut Mukhlis (2000: 5) PTK adalah suatu bentuk kajian yang bersifat sistematis reflektif oleh pelaku tindakan untuk memperbaiki kondisi pembelajaran yang dilakukan. Adapun tujuan utama dari PTK adalah untuk memperbaiki/meningkatkan pratek pembelajaran secara berkesinambungan, sedangkan tujuan penyertaannya adalah menumbuhkan budaya meneliti di kalangan guru (Mukhlis, 2000: 5).

Sesuai dengan jenis penelitian yang dipilih, yaitu penelitian tindakan, maka penelitian ini menggunakan model penelitian tindakan dari Kemmis dan Taggart (dalam Sugiarti, 1997: 6), yaitu berbentuk spiral dari sklus yang satu ke siklus yang berikutnya. Setiap siklus meliputi planning (rencana), action (tindakan), observation (pengamatan), dan reflection (refleksi). Langkah pada siklus berikutnya adalah perncanaan yang sudah direvisi, tindakan, pengamatan, dan refleksi. Sebelum masuk pada siklus 1 dilakukan tindakan 
pendahuluan yang berupa identifikasi permasalahan.

Instrumen yang digunakan dalam penelitian ini terdiri dari: (1) Silabus Yaitu seperangkat rencana dan pengaturan tentang kegiatan pembelajaran pengelolahan kelas, serta penilaian hasil belajar. (2) Rencana Pelajaran (RP). Yaitu merupakan perangkat pembelajaran yang digunakan sebagai pedoman guru dalam mengajar dan disusun untuk tiap putaran. Masing-masing RP berisi kompetensi dasar, indikator pencapaian hasil belajar, tujuan pembelajaran khusus, dan kegiatan belajar mengajar. (3) Tes formatif. Tes ini disusun berdasarkan tujuan pembelajaran yang akan dicapai, digunakan untuk mengukur kemampuan pemahaman konsep IPA pada pokok bahasan .... Tes formatif ini diberikan setiap akhir putaran. Bentuk soal yang diberikan adalah pilihan guru (objektif).

Data-data yang diperlukan dalam penelitian ini diperoleh melalui observasi pengolahan pengajaran berbasis inkuiri, dan tes formatif. Untuk mengetahui keefektivan suatu metode dalam kegiatan pembelajaran perlu diadakan analisa data. Pada penelitian ini menggunakan teknik analisis deskriptif kualitatif, yaitu suatu metode penelitian yang bersifat menggambarkan kenyataan atau fakta sesuai dengan data yang diperoleh dengan tujuan untuk mengetahui prestasi belajar yang dicapai siswa juga untuk memperoleh respon siswa terhadap kegiatan pembelajaran serta aktivitas siswa selama proses pembelajaran. Untuk menganalisis tingkat keberhasilan atau persentase keberhasilan siswa setelah proses belajar mengajar setiap putarannya dilakukan dengan cara memberikan evaluasi berupa soal tes tertulis pada setiap akhir putaran.

\section{HASIL PENELITIAN DAN PEMBAHASAN Hasil Penelitian}

Data penelitian yang diperoleh berupa hasil uji coba item butir soal, data observasi berupa pengamatan pengelolaan pengajaran berbasis inkuiri dan pengamatan aktivitas siswa dan guru pada akhir pembelajaran, dan data tes formatif siswa pada setiap siklus.

Data hasil uji coba item butir soal digunakan untuk mendapatkan tes yang betul-betul mewakili apa yang diinginkan. Data ini selanjutnya dianalisis tingkat validitas, reliabilitas, taraf kesukaran, dan daya pembeda. Data tes formatif untuk mengetahui peningkatan prestasi belajar siswa setelah diterapkan pengajaran berbasis inkuiri.

Pada akhir proses belajar mengajar siswa diberi tes formatif I dengan tujuan untuk mengetahui tingkat keberhasilan siswa dalam proses belajar mengajar yang telah dilakukan. Adapun data hasil penelitian pada siklus I adalah sebagai berikut:

Table 2. Nilai Tes Formatif Pada Siklus I

\begin{tabular}{|c|c|c|c|c|c|c|c|}
\hline \multirow{2}{*}{ No. Urut } & \multirow{2}{*}{ Nilai } & \multicolumn{2}{|c|}{ Keterangan } & \multirow{2}{*}{ No. Urut } & \multirow{2}{*}{ Nilai } & \multicolumn{2}{|r|}{ Keterangan } \\
\hline & & $\mathrm{T}$ & TT & & & $\mathrm{T}$ & TT \\
\hline 1 & 80 & $\sqrt{ }$ & & 13 & 90 & $\sqrt{ }$ & \\
\hline 2 & 50 & & $\sqrt{ }$ & 14 & 70 & $\sqrt{ }$ & \\
\hline 3 & 70 & $\sqrt{ }$ & & 15 & 50 & & $\sqrt{ }$ \\
\hline 4 & 40 & & $\sqrt{ }$ & 16 & 40 & & $\sqrt{ }$ \\
\hline 5 & 60 & & $\sqrt{ }$ & 17 & 80 & $\sqrt{ }$ & \\
\hline 6 & 80 & $\sqrt{ }$ & & 18 & 80 & $\sqrt{ }$ & \\
\hline 7 & 70 & $\sqrt{ }$ & & 19 & 70 & $\sqrt{ }$ & \\
\hline 8 & 60 & & $\sqrt{ }$ & 20 & 70 & $\sqrt{ }$ & \\
\hline 9 & 40 & & $\sqrt{ }$ & 21 & 50 & & $\sqrt{ }$ \\
\hline 10 & 80 & $\sqrt{ }$ & & 22 & 60 & & $\sqrt{ }$ \\
\hline 11 & 70 & $\sqrt{ }$ & & 23 & 70 & $\sqrt{ }$ & \\
\hline 12 & 80 & $\sqrt{ }$ & & 24 & 90 & $\sqrt{ }$ & \\
\hline Jumlah & 780 & 7 & 5 & Jumlah & 820 & 8 & 4 \\
\hline
\end{tabular}




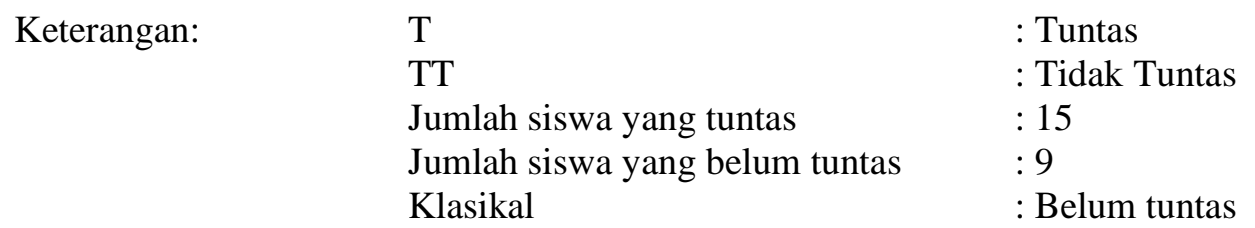

Tabel 3. Rekapitulasi Hasil Tes Formatif Siswa pada Siklus I

\begin{tabular}{clc}
\hline No & \multicolumn{1}{c}{ Uraian } & Hasil Siklus I \\
\hline 1 & Nilai rata-rata tes formatif & 66,67 \\
2 & Jumlah siswa yang tuntas belajar & 15 \\
3 & Persentase ketuntasan belajar & 62,50 \\
\hline
\end{tabular}

Dari tabel di atas dapat dijelaskan bahwa dengan menerapkan pengajaran berbasis inkuiri diperoleh nilai rata-rata prestasi belajar siswa adalah 66,67 dan ketuntasan belajar mencapai $62,50 \%$ atau ada 15 siswa dari 24 siswa sudah tuntas belajar. Hasil tersebut menunjukkan bahwa pada siklus pertama secara klasikal siswa belum tuntas belajar, karena siswa yang memperoleh nilai $\geq 65$ hanya sebesar $62,50 \%$ lebih kecil dari persentase ketuntasan yang dikehendaki yaitu sebesar $85 \%$. Hal ini disebabkan karena siswa masih canggung dengan diterapkannya pengajaran berbasis inkuiri.

Pada akhir proses belajar mengajar siswa diberi tes formatif II dengan tujuan untuk mengetahui tingkat keberhasilan siswa dalam proses belajar mengajar yang telah dilakukan. Instrument yang digunakan adalah tes formatif II. Adapun data hasil penelitian pada siklus II adalah sebagai berikut.

Table 4. Nilai Tes Formatif pada Siklus II

\begin{tabular}{|c|c|c|c|c|c|c|c|}
\hline \multirow{2}{*}{ No. Urut } & \multirow{2}{*}{ Nilai } & \multicolumn{2}{|c|}{ Keterangan } & \multirow{2}{*}{ No. Urut } & \multirow{2}{*}{ Nilai } & \multicolumn{2}{|r|}{ Keterangan } \\
\hline & & $\mathrm{T}$ & TT & & & $\mathrm{T}$ & TT \\
\hline 1 & 80 & $\sqrt{ }$ & & 13 & 80 & $\sqrt{ }$ & \\
\hline 2 & 60 & & $\sqrt{ }$ & 14 & 60 & & $\sqrt{ }$ \\
\hline 3 & 80 & $\sqrt{ }$ & & 15 & 80 & $\sqrt{ }$ & \\
\hline 4 & 80 & $\sqrt{ }$ & & 16 & 70 & $\sqrt{ }$ & \\
\hline 5 & 70 & $\sqrt{ }$ & & 17 & 70 & $\sqrt{ }$ & \\
\hline 6 & 60 & & $\sqrt{ }$ & 18 & 70 & $\sqrt{ }$ & \\
\hline 7 & 70 & $\sqrt{ }$ & & 19 & 60 & & $\sqrt{ }$ \\
\hline 8 & 60 & & $\sqrt{ }$ & 20 & 90 & $\sqrt{ }$ & \\
\hline 9 & 70 & $\sqrt{ }$ & & 21 & 80 & $\sqrt{ }$ & \\
\hline 10 & 80 & $\sqrt{ }$ & & 22 & 60 & & $\sqrt{ }$ \\
\hline 11 & 80 & $\sqrt{ }$ & & 23 & 80 & $\sqrt{ }$ & \\
\hline 12 & 70 & $\sqrt{ }$ & & 24 & 80 & $\sqrt{ }$ & \\
\hline Jumlah & 860 & 9 & 3 & Jumlah & 880 & 9 & 3 \\
\hline
\end{tabular}

Jumlah Skor 1740

Jumlah Skor Maksimal Ideal 2400

\% Skor Tercapai 72,50

\begin{tabular}{lll}
\hline Keterangan & $:$ T & $:$ Tuntas \\
& TT & $:$ Tidak Tuntas \\
& Jumlah siswa yang tuntas & $: 18$ \\
& Jumlah siswa yang belum tuntas & $: 6$ \\
& Klasikal & $:$ Belum tuntas
\end{tabular}


Tabel 5. Hasil Tes Formatif Siswa pada Siklus II

\begin{tabular}{clc}
\hline No & \multicolumn{1}{c}{ Uraian } & Hasil Siklus II \\
\hline 1 & Nilai rata-rata tes formatif & 72,50 \\
2 & Jumlah siswa yang tuntas belajar & 18 \\
3 & Persentase ketuntasan belajar & 75,00 \\
\hline
\end{tabular}

Dari tabel di atas diperoleh nilai rata-rata prestasi belajar siswa adalah 72,50 dan ketuntasan belajar mencapai $75,00 \%$ atau ada 18 siswa dari 24 siswa sudah tuntas belajar. Hasil ini menunjukkan bahwa pada siklus II ini ketuntasan belajar secara klasikal telah mengalami peningkatan sedikit lebih baik dari siklus I. Adanya peningkatan hasil belajar siswa ini karena siswa sudah mulai akrab dengan pengajaran berbasis inkuiri, disamping itu ada perasaan senang pada diri siswa dengan adanya cara belajar yang baru karena itu adalah pengamalan pertama bagi siswa.

Pada akhir proses belajar mengajar siswa diberi tes formatif III dengan tujuan untuk mengetahui tingkat keberhasilan siswa dalam proses belajar mengajar yang telah dilakukan. Instrumen yang digunakan adalah tes formatif III. Adapun data hasil penelitian pada siklus III adalah sebagai berikut:

Table 6. Nilai Tes Formatif pada Siklus III

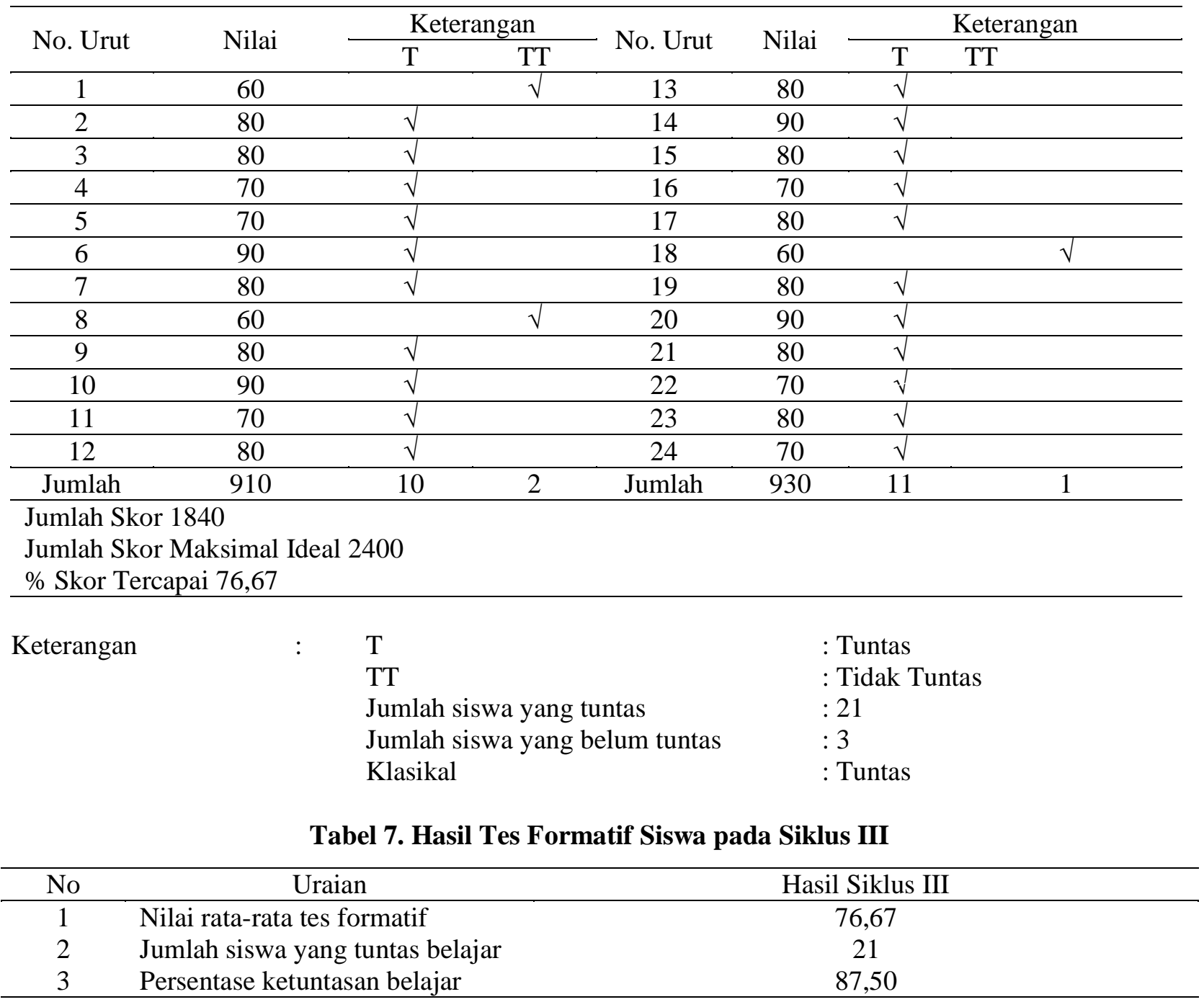


Berdasarkan tabel diatas diperoleh nilai ratarata tes formatif sebesar 76,67 dan dari 24 siswa yang telah tuntas sebanyak 21 siswa dan 3 siswa belum mencapai ketuntasan belajar. Maka secara klasikal ketuntasan belajar yang telah tercapai sebesar $87,50 \%$ (termasuk kategori tuntas). Hasil pada siklus III ini mengalami peningkatan lebih baik dari siklus II. Adanya peningkatan hasil belajar pada siklus III ini dipengaruhi oleh adanya peningkatan kemampuan siswa dalam memahami pembelajaran berbasis inkuiri. Disamping itu peningkatan kemampuan guru dalam mengelola pengajaran berbasis inkuiri semakin mantap.

\section{Pembahasan}

Melalui hasil peneilitian ini menunjukkan bahwa pengajaran berbasis inkuiri memiliki dampak positif dalam meningkatkan prestasasi belajar siswa. Hal ini dapat dilihat dari semakin mantapnya pemahaman dan penguasaan siswa terhadap materi yang telah disampaikan guru selama ini (ketuntasan belajar meningkat dari sklus I, II, dan III) yaitu masing-masing $62,50 \%$, $75,00 \%$, dan $87,50 \%$. Pada siklus III ketuntasan belajar siswa secara klasikal telah tercapai.

Berdasarkan analisis data, diperoleh aktivitas siswa dalam proses pengajaran berbasis inkuiri dalam setiap siklus mengalami peningkatan. Hal ini berdampak positif terhadap proses mengingat kembali materi pelajaran yang telah diterima selama ini, yaitu dapat ditunjukkan dengan meningkatnya nilai rata-rata siswa pada setiap siklus yang terus mengalami peningkatan. Berdasarkan analisis data, diperoleh aktivitas siswa dalam proses pembelajaran IPA dengan pengajaran berbasis inkuiri yang paling dominan adalah bekerja dengan menggunakan alat/media, mendengarkan/ memperhatikan penjelasan guru, dan diskusi antar siswa/antara siswa dengan guru. Jadi dapat dikatakan bahwa aktivitas isiswa dapat dikategorikan aktif.

Sedangkan untuk aktivitas guru selama pembelajaran telah melaksanakan langkah-langkah pengajaran berbasis inkuiri dengan baik. Hal ini terlihat dari aktivitas guru yang muncul di antaranya aktivitas membimbing dan mengamati siswa dalam mengerjakan kegiatan, menjelaskan/ melatih menggunakan alat, memberi umpan balik/evaluasi/tanya jawab dimana prosentase untuk aktivitas di atas cukup besar.

\section{SIMPULAN DAN SARAN Simpulan}

Dari hasil kegiatan pembelajaran yang telah dilakukan selama tiga siklus, dan berdasarkan seluruh pembahasan serta analisis yang telah dilakukan dapat disimpulkan sebagai berikut: (1) Pembelajaran dengan pengajaran berbasis inkuiri memiliki dampak positif dalam meningkatkan prestasi belajar siswa yang ditandai dengan peningkatan ketuntasan belajar siswa dalam setiap siklus, yaitu siklus I $(62,50 \%)$, siklus II $(75,00 \%)$, siklus III $(87,50 \%)$. (2) Penerapan pengajaran berbasis inkuiri mempunyai pengaruh positif, yaitu dapat meningkatkan motivasi belajar siswa untuk mempelajari pelajaran IPA yang ditunjukan dengan rata-rata jawaban siswa yang menyatakan bahwa siswa tertarik dan berminat dengan pengajaran berbasis inkuiri sehingga mereka menjadi termotivasi untuk belajar.

\section{Saran}

Dari hasil penelitian yang diperoleh dari uraian sebelumnya agar proses belajar mengajar IPA lebih efektif dan lebih memberikan hasil yang optimal bagi siswa, maka disampaikan saran sebagai berikut: (1) Untuk melaksanakan pengajaran berbasis inkuiri memerlukan persiapan yang cukup matang, sehingga guru harus mampu menentukan atau memilih topik yang benar-benar bisa diterapkan dengan pengajaran berbasis inkuiri dalam proses belajar mengajar sehingga diperoleh hasil yang optimal. (2) Dalam rangka meningkatkan prestasi belajar siswa, guru hendaknya lebih sering melatih siswa dengan berbagai metode pengajaran yang sesuai, walau dalam taraf yang sederhana, dimana siswa nantinya dapat menemuan pengetahuan baru, memperoleh konsep dan keterampilan, sehingga siswa berhasil atau mampu memecahkan masalahmasalah yang dihadapinya.

\section{DAFTAR PUSTAKA}

Arikunto, Suharsimi. 2002. Prosedur Penelitian Suatu Pendekatan Praktek. Jakarta: Rineksa Cipta.

Ali, Muhammad. 1996. Guru Dalam Proses Belajar Mengajar. Bandung: Sinar Baru Algesindon.

Daroeso, Bambang. 1989. Dasar dan Konsep Pendidikan Moral Pancasila. Semarang: Aneka Ilmu. 
Hadi, Sutrisno. 1982. Metodologi Research, Jilid 1. Yogyakarta: YP. Fak. Psikologi UGM.

Melvin, L. Siberman. 2004. Active Learning, 101 Cara Belajar Siswa Aktif. Bandung: Nusamedia dan Nuansa.

Ngalim, Purwanto M. 1990. Psikologi Pendidikan. Bandung: PT. Remaja Rosdakarya.

Nurhadi, dkk. Pembelajaran Kontekstual (Contextual Teaching and Learning/CTL) dan Penerapannya Dalam KBK. Malang: Universitas Negeri Malang (UM Press).

Riduwan. 2004. Belajar Mudah Penelitian untuk Guru-Karyawan dan Peneliti Pemula. Bandung: Alfabeta.

Sukmadinata, Nana Syaodih. 2004. Metode Penelitian Pendidikan. Bandung: PT. Remaja Rosdakarya.

Surakhmad, Winarno. 1990. Metode Pengajaran Nasional. Bandung: Jemmars. 